\title{
Designing a methodological concept for the diagnosis of early development of the main wheat diseases pathogens
}

\author{
Oksana Kremneva ${ }^{1, *}$, Roman Danilov ${ }^{1}$, Olga Tutubalina $^{2}$, Igor Sereda ${ }^{2}$, and Artem \\ Kurilov ${ }^{1}$ \\ ${ }^{1}$ All-Russian Research Institute of Biological Plant Protection, Krasnodar, 350039, Russia \\ ${ }^{2}$ M.V. Lomonosov Moscow State University, Moscow, 119991, Russia
}

\begin{abstract}
The studies presented in the article were carried out in 20182019 on the experimental field of the All-Russian Research Institute of Biological Plant Protection. The aim of the research was to assess the feasibility of diagnosing the early development of major diseases pathogens based on the results of ground-based spectrometry and the use of phytomonitoring technology, taking into account the genotypes of different winter wheat varieties. There were three options of the experimental plots for the research: the $1^{\text {st }}$ - protected against diseases by fungicides, the $2^{\text {nd }}$ - with an artificial infectious background, the $3^{\text {rd }}$ - with the natural development of diseases. According to the results of data analysis, the most significant changes in the spectral characteristics of the studied plant backgrounds were noted at the time of the first signs of disease in the form of a decrease in the spectral brightness coefficient in the near infrared range. Using special tools in the experimental plots, the following pathogens were identified before the appearing of disease symptoms: Blumeria graminis (DC.) Speer f. sp. tritici Marchal , Puccinia striiformis West., Pyrenophora tritici-repentis Died., Puccinia triticina Erikss. Data on the diseases development, plant infestation by pathogens are compared with spectrometric measurements.
\end{abstract}

Wheat is the main grain crop cultivated around the world. The global area occupied by wheat is 215.5 million hectares. According to the Ministry of Agriculture of the Russian Federation, in 2018 winter wheat occupied 15.3 million ha, which corresponds to the figure a year earlier. In Krasnodar Krai winter wheat occupies an area of 1.5 million hectares. This crop is exposed to a large range of leaf-stem pathogens [1-3]. The vital activity of phytopathogens causes a loss in the quality and quantity of grain, reducing yield to $90 \%$ [4, 5]. To provide perfect plant protection against pests, timely and accurate phytosanitary monitoring is very important [6]. Effective phytosanitary monitoring is possible only with the early detection of aerogenic infection and the sources of its origin [7]. There are studies

*Corresponding author: kremenoks@mail.ru 
on the detection of spores of Fusarium pathogens and rust pathogens in the air over wheat and sugar beet crops using special tools and methods [8 - 10]. The development of remote methods for diagnosing the crops conditions using data from remote sensing of the Earth is an extremely promising area nowadays [11-13]. There are some studies to identify differences in the development of phytopathogens in different crops based on hyperspectral measurements [14-16]. There are some known results of the studies on the development of remote methods for the detection of rust diseases in winter wheat crops based on changes in the spectral characteristics of plant objects [17]. Successful work was carried out to model the ecological niche of wheat septoria using remote sensing [18].

Thus, the development of fundamental scientific and methodological basis for the early diagnosis of the main wheat diseases pathogens using remote hyperspectral measurements and monitoring tools is extremely important.

The aim of the research is to develop methodological basis for diagnosing the early development of economically significant pathogens of wheat diseases based on analysis of ground spectrometric data and monitoring tools, taking into account the characteristics of the genotypes of different winter wheat varieties.

To achieve this goal, we organized test plots of four winter wheat varieties (Kuren, Bonus, Aksinya, Krasnodarskaya 99) on the experimental fields of ARRIBPP, which are characterized by different degrees of resistance to leaf-stem diseases [2]. Each site was divided into three zones: the $1^{\text {st }}$ - protected against diseases by fungicides (clean background), the $2^{\text {nd }}$ - with an artificial infectious background of brown rust (infected), the $3^{\text {rd }}$ - with the natural development of diseases. To develop brown and yellow rusts in the experimental plot, the method of artificial infection of winter wheat plants with spores of these phytopathogens was used [19-20]. Infection of winter wheat plants was carried out on April 16 in the "beginning of stem elongation" phase (phase Z 30-32). The development of yellow leaf spot, septoria and powdery mildew pathogens occurred upon a natural infectious background. The development of a clean background (without disease) was carried out by 2-replication treatment of the selected area with the Falcon KS systemic fungicide: 1st treatment 04.25.2019 (phase "flag-leaf"), 2nd 9.05.2019 (phase "beginning of flowering" Z 61). Disease recording was carried out, starting from the moment of the initial disease signs, which were noted on April 30, 2019 in the "flag leaf" phase (Z 40-47) and subsequently to the phase of "milk-wax ripeness of grain" $(Z$ 75) with an interval of $10-12$ days. The degree of plants damage by diseases was evaluated as a percentage according to the international methods [19-20].

Spectrometric measurements of wheat crops on test spots were carried out daily from the moment of artificial infection with phytopathogens until the appearance and amplification of visible symptoms of the disease using a FieldSpec 3 Hi-Res spectroradiometer [21].

Along with hyperspectral measurements, air samples were taken over crops and in crops of various varieties on a natural and artificial infectious background using the portable determinant of plant infestation OZR-1 mp [7].

In order to identify specific spectral ranges indicating the signs of changes caused by exposure to harmful objects, we analyzed the changes in the morphology of the spectral signatures of the spectral brightness coefficient (SBC) of plant objects depending on their actual condition, taken into account during field surveys (Figure 1). 


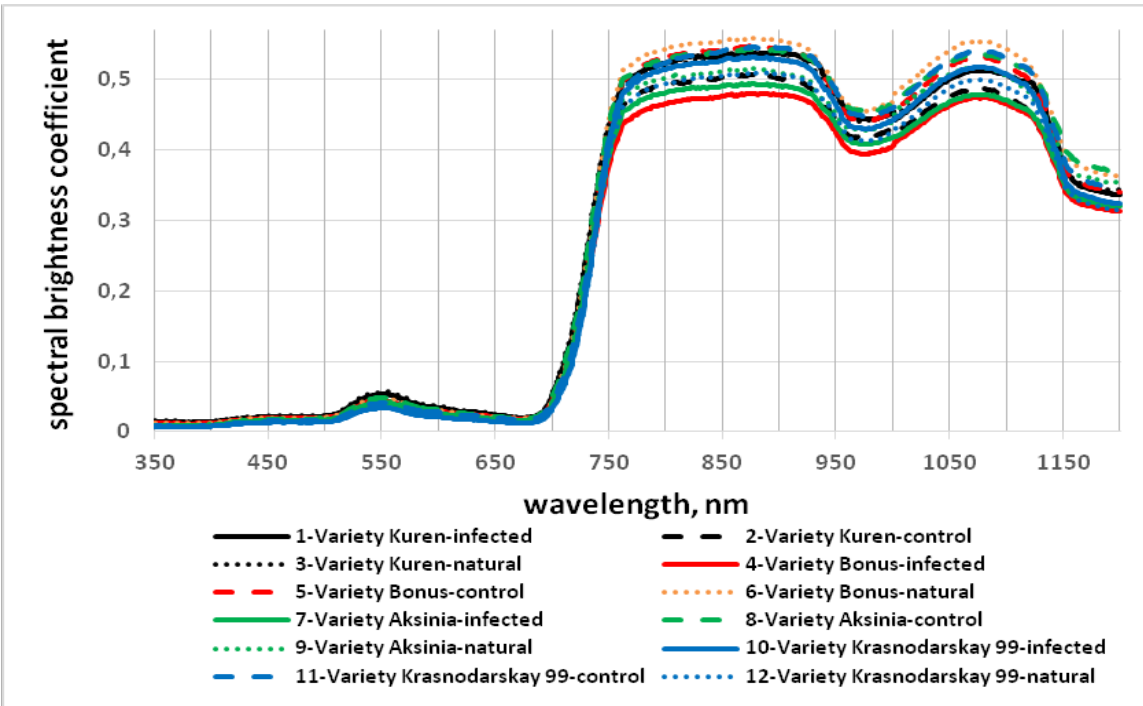

Fig. 1. Graphs of the average values of the SBC of infected, control, and natural backgrounds of different winter wheat varieties at the time of the first signs of disease (05.02.2019).

According to the results of the graphic data analysis, it was found that the most significant differences in the reflectivity of the studied objects appear in the near infrared range of the spectrum, therefore, an analysis of the change in the SBC values for all plots for the entire measurement period (April 26, 2019 - May 26, 2019) in the $800 \mathrm{~nm}$ channel was carried out in comparison with the data on the development of diseases and the degree of plants infestation in the crops of test plots (Table 1). The $800 \mathrm{~nm}$ channel is the center of the near infrared range and is often used by various types of film systems [22].

During the incubation period before the appearance of external diagnosed signs of the diseases development from April 26 to April 29, 2019, there were no significant changes in the reflectivity of winter wheat plants, indicating the influence of pathogens on the crops condition. The SBC values of the compared plant backgrounds in the $800 \mathrm{~nm}$ channel did not differ significantly.

At this time, with the help of special spore-trapping devices, the following pathogens were identified on test plots: Blumeria graminis, Puccinia striiformis, Pyrenophora triticirepentis, Puccinia triticina. Powdery mildew spores are predominantly quantitative compared with other pathogens. Moreover, the number of spores detected on the infected and natural backgrounds was 2-3 times higher than the values of control plots treated with the fungicide.

On all test plots without exception, spores of yellow rust in an amount of 1 to 9 were recorded. Single brown rust spores were found mainly on crops plots of the pathogen susceptible varieties Aksinya and Krasnodarskaya 99. No spores of septoria were found on any plot, while spores of tan spot were present on plots of all three backgrounds in the amount of 1 up to 3 pcs.

The first visible changes in the spectral characteristics of the studied plant backgrounds, which appeared in the form of a decrease in the spectral brightness coefficient (SBC) on infected plots of all varieties, were noted by analyzing data obtained from April 30 to May 2,2019 . At that moment the first single signs of yellow rust were recorded on the resistant variety Kuren, as well as single signs of $P$. tritici-repentis in the plots of the remaining varieties. 
Table 1. Temporary changes in the values of the spectral brightness coefficient at a wavelength of $800 \mathrm{~nm}$ in comparison with the data on the diseases development and the degree of winter wheat plants infestation in the crops of test plots

\begin{tabular}{|c|c|c|c|c|c|c|c|c|c|c|c|c|c|}
\hline \multirow{2}{*}{\multicolumn{2}{|c|}{$\begin{array}{l}\text { Diseases pathogens/ } \\
\text { SBC values }\end{array}$}} & \multicolumn{3}{|c|}{ Kuren variety } & \multicolumn{3}{|c|}{ Bonus variety } & \multicolumn{3}{|c|}{$\begin{array}{l}\text { Aksinya } \\
\text { variety }\end{array}$} & \multicolumn{3}{|c|}{$\begin{array}{c}\text { Variety } \\
\text { Krasnodarskaya } 99 \\
\end{array}$} \\
\hline & & $1^{* * *}$ & 2 & 3 & 1 & 2 & 3 & 1 & 2 & 3 & 1 & 2 & 3 \\
\hline \multicolumn{14}{|c|}{ 26-29.04.2019; Phase Z 40-47 «flag-leaf» } \\
\hline \multirow{2}{*}{ B. graminis } & $\mathrm{R}, \%{ }^{*}$ & 0 & 0 & 0 & 0 & 0 & 0 & 0 & 0 & 0 & 0 & 0 & 0 \\
\hline & $\mathrm{N}, \mathrm{pcs}^{* *}$ & 150 & 80 & 310 & 263 & 69 & 355 & 216 & 65 & 298 & 329 & 86 & 220 \\
\hline \multirow{2}{*}{ P. triticina } & $\mathrm{R}, \%{ }^{*}$ & 0 & 0 & 0 & 0 & 0 & 0 & 0 & 0 & 0 & 0 & 0 & 0 \\
\hline & N,pcs ${ }^{* *}$ & 0 & 0 & 0 & 0 & 0 & 1 & 1 & 1 & 1 & 1 & 0 & 0 \\
\hline \multirow{2}{*}{ P. striiformis } & $\mathrm{R}, \%^{*}$ & 0 & 0 & 0 & 0 & 0 & 0 & 0 & 0 & 0 & 0 & 0 & 0 \\
\hline & $\mathrm{N}, \mathrm{pcs}^{* * *}$ & 2 & 7 & 6 & 4 & 3 & 9 & 3 & 3 & 2 & 1 & 6 & 4 \\
\hline \multirow{2}{*}{ S. tritici } & $\mathrm{R}, \%^{*}$ & 0 & 0 & 0 & 0 & 0 & 0 & 0 & 0 & 0 & 0 & 0 & 0 \\
\hline & N,pcs ${ }^{* *}$ & 0 & 0 & 0 & 0 & 0 & 0 & 0 & 0 & 0 & 0 & 0 & 0 \\
\hline \multirow{2}{*}{$\begin{array}{l}P . \text { tritici- } \\
\text { repentis }\end{array}$} & $\mathrm{R}, \%{ }^{*}$ & 0 & 0 & 0 & 0 & 0 & 0 & 0 & 0 & 0 & 0 & 0 & 0 \\
\hline & N,pcs ${ }^{* *}$ & 2 & 1 & 1 & 3 & 1 & 2 & 1 & 1 & 1 & 2 & 3 & 4 \\
\hline \multicolumn{2}{|l|}{ SBC values } & 0,48 & 0,48 & 0,47 & 0,46 & 0,47 & 0,47 & 0,48 & 0,48 & 0,48 & 0,46 & 0,46 & 0,46 \\
\hline \multicolumn{14}{|c|}{ 1-2.04.2019; Phase Z 40-47 «flag-leaf» } \\
\hline \multirow{2}{*}{ B. graminis } & $\mathrm{R}, \%^{*}$ & 0,1 & 0 & 0,1 & 0,1 & 0 & 0,1 & 0,1 & 0,1 & 0,1 & 1 & 0 & 0,1 \\
\hline & N,pes ${ }^{* * *}$ & 110 & 30 & 62 & 67 & 32 & 56 & 110 & 36 & 164 & 193 & 47 & 122 \\
\hline \multirow{2}{*}{ P. triticina } & $\mathrm{R}, \%^{*}$ & 0 & 0 & 0 & 0 & 0 & 0 & 0,1 & 0 & 0,1 & 0,1 & 0,1 & 0,1 \\
\hline & $\mathrm{N}, \mathrm{pcs}^{* *}$ & 2 & 2 & 5 & 4 & 2 & 3 & 1 & 1 & 3 & 4 & 9 & 5 \\
\hline \multirow{2}{*}{ P. striiformis } & $\mathrm{R}, \%{ }^{*}$ & 0,1 & 0 & 0,1 & 0 & 0 & 0 & 0 & 0 & 0 & 0 & 0 & 0 \\
\hline & N,pcs ${ }^{* *}$ & 23 & 1 & 4 & 3 & 1 & 2 & 33 & 17 & 7 & 7 & 16 & 1 \\
\hline \multirow{2}{*}{ S. tritici } & $\mathrm{R}, \%^{*}$ & 0,1 & 0 & 0,1 & 0,1 & 0 & 0,1 & 0,1 & 0 & 0 & 0,1 & 0 & 0,1 \\
\hline & $\mathrm{N}, \mathrm{pcs}^{* *}$ & 0 & 0 & 0 & 0 & 0 & 0 & 0 & 0 & 0 & 0 & 0 & 0 \\
\hline \multirow{2}{*}{$\begin{array}{l}P . \text { tritici- } \\
\text { repentis }\end{array}$} & $\mathrm{R}, \%^{*}$ & 0,1 & 0 & 0,1 & 0,1 & 0 & 0,1 & 0,1 & 0 & 0,1 & 0,1 & 0 & 0,1 \\
\hline & $\mathrm{N}, \mathrm{pcs}^{* *}$ & 1 & 1 & 2 & 1 & 1 & 4 & 4 & 1 & 11 & 1 & 1 & 2 \\
\hline \multicolumn{2}{|l|}{ SBC values } & 0,49 & 0,51 & 0,48 & 0,48 & 0,53 & 0,53 & 0,49 & 0,54 & 0,49 & 0,49 & 0,52 & 0,51 \\
\hline \multicolumn{14}{|c|}{ 10.05.2019; Phase Z 61 «beginning of flowering» } \\
\hline \multirow{2}{*}{ B. graminis } & $\mathrm{R}, \%^{*}$ & 5 & 3 & 3 & 3 & 3 & 5 & 3 & 3 & 3 & 3 & 3 & 3 \\
\hline & $\mathrm{N}, \mathrm{pcs}{ }^{* *}$ & 200 & 66 & 300 & 47 & 100 & 323 & 115 & 66 & 236 & 153 & 35 & 180 \\
\hline \multirow{2}{*}{ P. triticina } & $\mathrm{R}, \%{ }^{*}$ & 0 & 0 & 0 & 1 & 0 & 0,1 & 1 & 0 & 0,1 & 5 & 1 & 5 \\
\hline & N,pcs ${ }^{* *}$ & 2 & 2 & 10 & 10 & 1 & 10 & 2 & 1 & 1 & 33 & 23 & 54 \\
\hline \multirow{2}{*}{ P. striiformis } & $\mathrm{R}, \%{ }^{*}$ & 10 & 0 & 1 & 10 & 5 & 10 & 10 & 0,1 & 1 & 5 & 1 & 5 \\
\hline & $\mathrm{N}, \mathrm{pcs}^{* *}$ & 2 & 1 & 10 & 16 & 11 & 18 & 14 & 2 & 12 & 2 & 1 & 13 \\
\hline S tritio & $\mathrm{R}, \%^{*}$ & 3 & 3 & 3 & 1 & 1 & 1 & 3 & 3 & 3 & 3 & 3 & 3 \\
\hline ग. trullel & $\mathrm{N}, \mathrm{pcs}{ }^{* *}$ & 0 & 0 & 0 & 0 & 0 & 0 & 0 & 0 & 0 & 0 & 0 & 0 \\
\hline P. tritici- & $\mathrm{R}, \%{ }^{*}$ & 1 & 1 & 1 & 1 & 1 & 1 & 1 & 1 & 1 & 1 & 1 & 1 \\
\hline repentis & N,pcs ${ }^{* *}$ & 4 & 0 & 3 & 1 & 0 & 3 & 13 & 10 & 11 & 6 & 6 & 7 \\
\hline SBC val & & 0,49 & 0,36 & 0,45 & 0,36 & 0,41 & 0,41 & 0,42 & 0,44 & 0,44 & 0,47 & 0,47 & 0,48 \\
\hline
\end{tabular}

The nature of the quantitative distribution of powdery mildew spores didn't change compared with the previous period before the appearance of external signs of disease. The number of brown rust spores increased to $2-5$ pcs. for a plot. The largest number of yellow rust spores was recorded on the infectious backgrounds of the varieties Kuren and Aksinya amounting to 23 and 33 pcs. respectively, and the average amount in the remaining plots 
varied from 1 to 17 pcs. The number of pyrenophorosis spores also increased up to 2-4 pcs. with a maximum quantity of 11 pcs. on the natural background of Aksinya variety.

During the period of the most intensive development of diseases from May 10 to May 25,2019 , powdery mildew spores predominated, while the development of the disease, regardless of variety, on all plots averaged 3-5\%. The most intensive development of brown rust amounting up to $5 \%$ was observed on the infected and natural backgrounds of the pathogen-susceptible variety Krasnodarskaya 99. The highest number of pathogen spores from 33 to 54 pcs. was recorded on the same backgrounds. The maximum development of yellow rust was $10 \%$ and it was recorded on the infected and natural backgrounds of the varieties Kuren, Bonus and Aksinya. Therefore, the number of spores of yellow rust found on these plots was the largest and ranged from 10 to 18 pcs. The minimum percentage of pathogen development was noted on the control backgrounds of all four varieties. The development of Septoria spot reached 1-3\% on all plots. Tan spot was also observed on all plots with a degree of development of $1 \%$, and the average number of spores varied from 1 to $7 \mathrm{pcs}$. The greatest number of pathogen spores amounting up to 11 13 pcs. was found on the plots with crops of the Aksinya variety, which is susceptible to this pathogen.

Despite the greater development of the pathogenic background of infected and natural plots compared with the control, the values of the spectral response in the $800 \mathrm{~nm}$ channel were ambiguous. Thus, the SBC values of the control background of the Kuren variety was characterized by a lower rate compared to infected and natural backgrounds. On the remaining varieties, the SBC values of the three compared backgrounds were almost equal. Most likely, this can be explained by the imposition of other factors causing inaccuracies in the measurements: uneven seeding, the effects of external harmful objects, planned field treatment, inaccuracies in observing the spectrometry technique.

A key feature of the studies is the identification of the spectral characteristics of plants damaged by pathogens, not under the laboratory conditions, but in their natural environment. This work showed the difficulty of collecting and analyzing information under these conditions, but also indicated their fundamental feasibility. We found that, according to the multimodal data of ground-based spectrometry, it is possible to detect changes in the conditions of winter wheat crops in the early stages of pathogen development.

Using special tools in the experimental plots, the following pathogens were identified before the appearing of disease symptoms: $B$. graminis, $P$. striiformis, $P$. tritici-repentis, $P$. triticina. The system of the remote monitoring of phytopathogen spores using special equipment has shown its viability and the ability to monitor economically significant diseases in detail.

These studies are supposed to be continued in 2020, taking into account the experience of 2019 and the development of the methods allowing to improve the reliability of the results.

The research was supported by the RFBR grant and the Administration of Krasnodar Krai No. 19-416-230043 r_a

\section{References}

1. J.A. Kolmer, M.E. Hughes, Eur. Phys. J. Plant Disease. 98, 1 (2014) https://apsjournals.apsnet.org/doi/10.1094/PDIS-01-12-0048-SR

2. I.P. Matveeva, Yu.S. Kim, O.F. Vaganova, O.O. Miroshnichenko, O.Yu. Kremneva, G.V.Volkova, International Research Journal. 12-2(78), 40-44 (2018) https://doi.org/10.23670/IRJ.2018.78.12.044 
3. A. Kokhmetova, M. Atishova, Z. Sapakhova, O.Yu Kremneva, G.V. Volkova, Plant Pathol. J. 99(1), 161-167 (2017) http://dx.doi.org/10.4454/jpp.v99i1.3812

4. G. Volkova, O. Vaganova, O. Kudinova, IOP Conference Series: Earth and Environmental Science, 403, $\quad 012018 \quad$ (2019) https://iopscience.iop.org/article/10.1088/1755-1315/403/1/012018

5. I. P. Matveeva, G.V Volkova, Vestnik of Ulyanovsk state agricultural academy. 2(46), 102-116 (2019) http://doi.org/DOI:\%2010.18286/1816-4501-2019-2-102-116

6. C. Sanin, Bulletin of agrarian science. 3(66), 35-39 (2017) https://www.elibrary.ru/item.asp?id=29369133

7. Yu.G. Sokolov, V.T. Sadkovsky, O. Yu. Kremneva, R.Yu. Danilov, A.A. Pachkin, R.A. Zelensky, A.A. Kurilov, International Research Journal. 12-2(78), 29-33 (2018) https://doi.org/10.23670/IRJ.2018.78.12.042

8. T.M. Wieczorek, L.N. Jørgensen, A.L. Hansen, L. Munk, A.F. Justesen, European Journal of Plant Pathology. 138, 775-785 (2014) https://doi.org/10.1007/s10658-0130349-6

9. M. Almaguer, M.-J. Aira, F. Javier Rodríguez-Rajo, T. I. Rojas, International Journal of Biometeorology. 58, 1459-1470 (2014) https://doi.org/10.1007/s00484-013$\underline{0748-6}$

10. T. Quesada1, J. Hughes1, K. Smith, K. Shin, P. James, J. Smith, Forests. 9(10), 586 (2018) https://www.mdpi.com/1999-4907/9/10/586

11. R.Yu. Danilov, V.Ya. Ismailov, V.A. Tretyakov, O.Yu. Kremneva, Yu.V. Shumilov, A.A. Rizvanov, V.V. Krivoshein, I.A. Kostenko, Achievements of Science and Technology of AICis. 32(10), 82-86 (2018) http://agroapk.ru/2018-g/138-archive/102018/2800-2018-10-19-ru

12. C. Bravo, D. Moshou, J. West, A. McCartney, H. Ramon, Biosystems Engineering J.. 84(2), 137-145 (2003) https://doi.org/10.1016/S1537-5110(02)00269-6

13. Y. Wanga, Sh. Ziaa, S. Owusu-Adua, R. Gerhardsb, J. Müller, APCBEE Procedia. 8, 199 - 203 (2014) https://doi.org/10.1016/j.apcbee.2014.03.027

14. D. Krezhova, B. Dikova, S. Maneva, Bulgarian J. Agricultural Science. 20(5), 1142 1150 (2014) https://doi.org/10.1117/12.974722

15. T.A. Gurova , D.N. Klimenko , O.S. Lugovskaya, O.V. Elkin , V.I. Kozik, Achievements of Science and Technology of AICis. 33(10), 71-75 (2019) https://doi.org/ $\underline{10.24411 / 0235-2451-2019-11016}$

16. D. Krezhova, Soybean-Genetics and Novel Techniques for Yield Enhancement , InTech Publisher. 11, 215-256 (2011) https://doi.org/ 10.5772/24741

17. R.Yu. Danilov, O.Yu. Kremneva, V.Ya. Ismailov, V.A. Tretyakov, A.A. Rizvanov, V.V. Krivoshein, A.A. Pachkin, Current problems in remote sensing of the earth from space. 17(1), 113-127 (2020) https://doi.org/ 10.21046/2070-7401-2020-17-1-113$\underline{127}$

18. D.V. Malakhov, N.Yu. Tsychueva, I.S. Vitkovskaya, Current problems in remote sensing of the earth from space. 14(1), 113-124 (2017) https://doi.org/ 10.21046/20707401-2017-14-1-113-124

19. A.P. Roelfs, R.P. Singh, E.E. Saari, Rust diseases of wheat: concepts and methods management

https://rusttracker.cimmyt.org/wpcontent/uploads/2011/11/rustdiseases.pdf

20. M. Koyshibaev, A.O. Sagitov. Protection of grain crops from especially dangerous diseases. (2012).

21. FieldSpec 3 User Manual. ASD Document $\mathbf{6 0 0 5 4 0 ,} 110 \quad$ (2010) https://www.manualslib.com/manual/1431971/Asd-Fieldspec-3.html

22. J.L. Hatfield, A.A. Gitelson, J.S. Schepers, C.L. Walthall. Supplement to Agronomy Journal. 117-131 (2008) https://doi.org/10.2134/agronj2006.0370c 